Bioedusiana

Vol. 02, No. 01, Sep 2017

ISSN $2477-5193$

\title{
PENGARUH KONSENTRASI M-BIO TERHADAP KECEPATAN PENGOMPOSAN SAMPAH ORGANIK PASAR
}

\author{
H. Endang Surahman ${ }^{1}$, Mufti Ali ${ }^{1}$, Rita Fitriani ${ }^{1}$ \\ ${ }^{1}$ Jurusan Pendidikan Biologi Fakultas Keguruan dan Ilmu Pendidikan \\ Universitas Siliwangi Tasikmalaya \\ J1. Siliwangi No. 24 Kota Tasikmalaya 46115 \\ email: e.surahman@unsil.ac.id
}

\begin{abstract}
The purpose of the research was to know the impact of M-Bio concentration to composting speed of market vegetable waste. Qualitative description used as the research method, the research conducted at Botany Laboratory of Biology Education Department of Faculty of Teaching and Education Science of Siliwangi University as long as four month since prepare to compost acquired. Material that used in this research was market vegetable waste with observation manual as the research instrument. The research showed that there was the impact of M-Bio concentration to composting speed of market vegetable waste, the concentration that faster on composting was $0,1 \mathrm{M}$ concentration or $10 \mathrm{ml}$ M-Bio per $100 \mathrm{ml}$ sugar water.
\end{abstract}

Key words: M-Bio, Concentration, Composting, Speed, Waste

\begin{abstract}
ABSTRAK
Tujuan penelitian ini adalah untuk mengetahui pengaruh konsentrasi M-Bio terhadap kecepatan pengomposan sampah sayur pasar. Metode penelitian yang digunakan adalah deskriptif kualitatif, penelitian dilakukan di Laboratorium Botani Jurusan Pendidikan Biologi FKIP Unsil selama empat bulan dari mulai persiapan sampai diperoleh kompos. Bahan yang digunakan dalam penelitian adalah sampah sayur pasar, dengan instrument berupa pedoman observasi. Hasil penelitian menunjukkan bahwa terdapat pengaruh konsentrasi M-Bio terhadap kecepatan pengomposan sampah sayur pasar, konsentrasi yang paling cepat pengomposannya adalah konsentrasi $0,1 \mathrm{M}$ atau $10 \mathrm{ml}$ M-Bio per $100 \mathrm{ml}$ air gula.
\end{abstract}

Kata kunci: konsentrasi, kecepatan, kompos, M-Bio, sampah

\section{PENDAHULUAN}

Salah satu permasalahan yang belum terpecahkan di hampir setiap daerah adalah tentang sampah, baik dalam pembuangannya, pengelolaannya maupun dalam mengolahnya (recycle). Munculnya permasalahan tersebut dapat disebabkan oleh beberapa sumber, yaitu karena tidak adanya lahan untuk membuang sampah sebagai tempat sampah akhir, karena kurangnya kesadaran dari warga dalam membuang sampah tersebut, karena kurangnya pengetahuan warga dalam mengelola sampah, dan kurangnya pengetahuan untuk mengolah kembali sampah tersebut 
menjadi sesuatu yang berguna (recycle).

Berdasarkan pengamatan di hampir setiap tempat pembuangan sampah akhir (TPA) para pemulung hanya memunguti sampah-sampah yang dapat dijual yang berupa sampah anorganik saja, sedangkan sampah-sampah organiknya tidak pernah diperhatikan sama sekali dan dibiarkan begitu saja. Padahal sampah organik yang dihasilkan setiap harinya sangatlah besar, karena sumber dari sampah tersebut berasal dari rumah tangga dan yang paling besar dari pasar, dengan demikian maka sampah organic terutama yang berasal dari pasar akan semakin menumpuk di tempat pembuangan sampah akhir.

Sampah secara umum dapat diartikan sebagai barang atau benda yang dibuang karena tidak terpakai lagi. Menurut Cointreau, sampah adalah suatu barang atau material yang dibuang atau dilepas sebagai yang tidak bernilai (Sandra J. Cointreau, 1982:4). Selain itu sampah dapat pula diartikan sebagai semua jenis buangan atau kotoran padat yang berasal dari rumah tinggal, perkantoran, rumah penginapan, hotel, rumah makan, pasar, bangunan umum, pabrik maupun industri, termasuk puingpuing sisa bangunan dan besi (bekas) kendaraan bermotor, dan lainnya yang sejenis. Oleh karena itu sampah merupakan sisa proses produksi dari aktivitas manusia, maka sampah termasuk salah satu jenis limbah. Dengan demikian limbah diartikan sebagai sisa proses produksi. Oleh karena itu sumber sampah dapat digolongkan atas sampah yang berasal dari kegiatan rumah tangga, kegiatan perdagangan, dan kegiatan perindustrian.

Sampah yang dihasilkan dari rumah tangga berdasarkan sifatnya dapat dibedakan menjadi sampah organik dan sampah anorganik. Sampah organik (degradable refuse) adalah sampah yang mengandung senyawa-senyawa organik sehingga dapat diurai (didegredasi) oleh dekomposer atau mikroba. Misalnya daun, sisa sayur-sayuran, buahbuahan, ranting, sisa-sisa makanan, dan kertas. Adapun sampah anorganik (nondegradable refuse) adalah sampah yang tersusun dari bahan anorganik sehingga tidak dpat diurai (didegredasi) oleh dekomposer atau mikroba, misalnya plastik, gelas (kaca), logam (metal), keramik, dan bahan sintetis.

Sampah organik yang tertimbun di tempat pembuangan sampah akan terurai kembali dengan bantuan dekomposer, sehingga terjadilah proses daur ulang. Solid Waste Management Study Group mengemukakan bahwa, sampah organik dapat dirubah secara langsung menjadi kompos tanaman (Solid Waste Management Study Group, 1992:98). Proses perubahan tersebut terjadi secara alami melalui proses fisika, kimiawi, dan biologis serta sangat berguna dalam menjaga dan/atau meningkatkan kesuburan tanah. Sehubungan dengan penguraian sampah organik oleh 
dekomposer, Turk mengemukakan jika sebagian sampah organik membusuk oleh bakteri, cacing, dan organisme lainnya, dapat meningkatkan kesuburan tanah dan tanah siap untuk berproduksi; Proses ini disebut kompos (composting) (Jonathan Turk, 1989:350).

Upaya pengelolaan sampah mutlak perlu untuk dilakukan, salah satunya adalah melalui pendaurulangan sampah. Penting-nya pendaurulangan sampah saat ini tidak mungkin terhindarkan baik dalam produksi maupun konsumsi perlu dijadikan pegang-an dalam berbagai kebijaksanaan pembangunan industri (Mohamad Soerjani, 1997:95).

Pengelolaan atau penanggulangan sampah, terutama sam-pah rumah tangga harus dilakukan secara baik, efektif, dan ekonomis. Apabila ketiga hal tersebut tidak diperhatikan di dalam penang-gulangan sampah, dapat menim-bulkan gangguan bagi kehidupan manusia baik secara langsung maupun tidak langsung. Selain itu sampah juga dapat menimbulkan gangguan terhadap lingkungan hidup.

Pupuk organik adalah pupuk yang sebagian besar atau seluruhnya terdiri atas bahan organik yang berasal dari sisa tanaman, dan atau hewan yang telah mengalami rekayasa berben-tuk padata atau cair yang digunakan untuk memasok bahan organik, memiliki sifat fisik, kimia, dan biologi tanah (Peraturan Mentan RI, No.2/Pert/HK.060/2/ 2006).
Pupuk organik tidak meninggalkan sisa asam anorganik di dalam tanah dan mempunyai kadar persenyawaan C-organik yang tinggi. Pupuk organik kebanyakan tersedia di alam (tersaji secara alamiah), misalnya kompos, pupuk kandang, pupuk hijau, dan guano (Sumekto, 2006).

Kompos merupakan istilah untuk pupuk organik buatan manusia yang dibuat dari proses pembusukan sisasisa buangan makhluk hidup (tanaman maupun hewan). Proses pembuatan kompos dapat secara aerob dan anaerob yang saling menunjang pada konsisi lingkungan tertentu. Secara keseluruhan proses ini disebut dekomposisi (Yuwono, 2005).

Sedangkan menurut Bahar, Yul H. (1996:21) kompos adalah humus yang merupakan hasil proses biologis yang berasal dari sampah sebagai hasil interaksi yang kompleks dari berbagai organisme.

Selanjutnya ada juga yang mengartikan kompos sebagai bahanbahan organik (sampah organik) yang telah mengalami proses pelapukan karena adanya interaksi antara mikroorganisme (bakteri pembusuk) yang bekerja didalamnya (L. Murbandono H.S., 2000:7). Masih dalam buku tersebut, dikatakan bahwa kompos merupakan salah satu jenis pupuk organik, karena kahadiran pupuk organik sangat diharapkan, maka berarti kehadiran pupuk kompos pun demikian. Demikian juga pendapat yang menyatakan bahwa kompos 
merupakan hasil fermentasi atau dekomposisi dari bahan-bahan organik seperti tanaman, hewan, atau limbah organik lainnya. Kompos yang digunakan sebagai pupuk disebut pula pupuk organik karena penyusunnya terdiri dari bahanbahan organik (Yovita Hety Indriani, 2000:3).

Definisi lain mengenai kompos adalah bahwa kompos dihasilkan dengan mendekompo--sisi bahanbahan organik seperti sampah. Sistem kompos adalah cara penyimpanan kompos sedemikian sehingga dapat menerima udara dan menyesuaikan temperaturnya untuk terjadinya dekomposisi (Sustainable Building Sourcebook, 2001). Cara peng-komposan merupakan cara sederhana dan dapat menghasilkan produk kompos atau pupuk yang mempunyai nilai ekonomi (Sa'id Gumbira, 1987:38).

Sedangkan pendapat lain mengatakan bahwa proses pembuatan kompos (composting) merupakan proses biologis yang mengubah sampah menjadi humus sebagai interaksi yang kompleks dari organisme tanah yang terdapat secara alami. Organisme yang terlibat dalam proses pembuatan kompos adalah: bakteri, jamur, protozoa, nematoda, tungau, cacing, dan berbagai organisme lainnya.

M-Bio sebagai pupuk hayati/biologis atau biofeertilizer merupakan kultur campuran dari mikroorganisme yang menguntungkan (Ragi/yeast, Lactobacillus sp., Selubizing phospate bacteriae, dan Azospirillum sp.), dan diaplikasikan sebagai inokulan untuk meningkatkan keragaman dan populasi dalam transformasi dan daur ulang berbagai hara serta produksi berbagai senyawa atau metabolit (hormon dan lain-lain) yang dapat mendukung pertumbuhan tanaman, sehingga aplikasinya cocok bagi pertanian yang berwawasan lingkungan (Rudi Priyadi dan M. Iskandar Makmun, 1997:1).

Adapun fungsi dan peranan mikroorganisme yang terdapat dalam M-Bio adalah sebagai berikut: mendekomposisi bahan organik secara fermentasi yang menguntungkan dan menimbulkan aroma yang harum; melarutkan zatzat anorganik dan zat-zat/senyawa organik, mening-katkan humus tanah dan memperbaiki sifat tanah; memben-tuk senyawa anti bakteri, ester, antioksidan (mencegah $\mathrm{O}_{2}$ yang berasosiasi dengan penyakit tertentu dari tanaman, hewan ataupun manusia), dan beberapa senyawa yang merangsang pertumbuhan tanaman; menekan atau mencegah patogen serta mengurangi atau menghilangkan fermentasi yang merugikan (dekomposisi pembusukan dan menimbulkan bau busuk), pembentukan amonia, $\mathrm{H}_{2} \mathrm{~S}$, dan beberapa senyawa karbon serta gas-gas yang berbahaya yang dihasilkan oleh mikroba yang merugikan. Hal seperti tersebut ada yang menyebutnya dengan bioremediasi yaitu pemanfaatan biota, khususnya mikroorganisme 
(bakteri atau kapang heteritropik), guna mendegredasi bahan organik atau anorganik berbahaya yang mencemari suatu sumber daya dengan menggunakannya sebagai substrat (materi inokulum) (Mohamad Soejani, 1997:97).

Secara rinci fungsi dan peranan dari masing-masing mikroba yang terdapat dalam M-Bio adalah sebagai berikut:

a. Ragi/yeast, menghasilkan berbagai enzim dan hormon sebagai senyawa bioaktif untuk pertumbuhan tanaman.

b. Lactobacillus sp., menghasil-kan asam laktat meningkatkan dekomposisi atau pemecahan bahan organik seperti lignin dan selolusa.

c. Selubizing Phosphate bacte-riae, melarutkan $\mathrm{P}$ yang tidak tersedia dalam tanah menjadi bentuk $\mathrm{P}$ yang tersedia bagi tanaman (fungsi $\mathrm{P}$ bagi tanaman sangat penting).

d. Azospirillum sp., mengikat nitrogen udara $\left(\mathrm{N}_{2}\right)$ dan meningkatkan kualitas lingkungan tanah (Rudi Priadi dan M. Iskandar Makmun, 1997:23).

Kultur campuran mikroorganisme yang terdapat dalam M-Bio bekerja secara sinergis untuk memfermentasi bahan organik baik yang terdapat di alam/tanah maupun bahan organik yang telah disediakan sebelumnya (dalam pembuatan pupuk organiksecara fermentasi). Proses perombakan/ dekomposisi bahan organik menjadi zat-zat dalam bentuk ion yang tersedia bagi tanaman berlangsung relatif lama, sedangkan pemberian bahan organik yang belum matang dapat berakibat negatif bagi tanaman, karena dalam proses tersebut akan mengeluarkan gas dan panas. Namum dengan pemakaian M-Bio akan mampu memfermentasi bahan organik tersebut dalam waktu relatif cepat serta tidak mengeluarkan bau busuk, namum bau atau aroma yang ditimbulkannya adalah khas (enek). Proses fermentasi tersebut menghasilkan senyawa organik (protein, gula, asam laktat, asamamino, alkohol, dan vitamin) yang mudah tersedia dan dapat diserap langsung oleh tanaman (Rudi Priadi dan M. Iskandar Makmun, 1997:4).

Penelitian yang telah dilakukan diantaranya adalah oleh Nyimas Yanqoritha yang hasilnya adalah Hasil penelitian diperoleh untuk pembuatan kompos dengan menggunakan aktivator yang berbeda yaitu tanpa aktivator, EM4, MOD 71, dan Kotoran domba, yang sesuai dengan titik optimasi dari grafik $\mathrm{C}, \mathrm{N}$, ratio $\mathrm{C} / \mathrm{N}$, dan $\mathrm{P}$ sesuai dengan tabel kompos secara SNI adalah kompos yang menggunakan aktivator EM4 yaitu pada kadar C dimulai 30.19 menuju 35.89 menurun ke 31.17; dan kadar $\mathrm{N}$ dimulai 1.57 menuju 1.89 menurun 1.53 ; dan kadar ratio $\mathrm{C} / \mathrm{N}$ dimulai 19.22 menuju 20.49 menurun 20.33; dan untuk kadar $\mathrm{P}$ 
dimulai 2.73 menuju 2.69 menurun 2.72 .

Selanjutnya penelitian yang telah dilakukan dengan objeknya sampah adalah yang dilakukan oleh Ramadhan, Aprian P. dan Munawar Ali yang hasilnya adalah Hasil dekomposisi dengan efeiensi yang terbaik dalam menguraikan sampah plastik terjadi pada suhu $420{ }^{\circ} \mathrm{C}$ dengan waktu operasi 60 menit.

\section{TUJUAN PENELITIAN}

a. Menghasilkan produk berupa pupuk kompos organik;

b. Mengetahui konsentrasi M-Bio yang paling cepat dalam pengomposan;

c. Mengetahui pengomposan yang paling cepat.

\section{METODE PENELITIAN}

Metode penelitian yang digunakan dalam penelitian ini adalah metode eksperimen, dengan perlakuannya adalah sebagai berikut: Perlakuan A : pemberian M-Bio dengan kon-sentrasi $0,1 \mathrm{M}$

Perlakuan B : pemberian M-Bio dengan konsentrasi $0,05 \mathrm{M}$

Perlakuan C : pemberian M-Bio dengan konsentrasi $0,033 \mathrm{M}$

Perlakuan D : pemberian M-Bio dengan konsentrasi $0,025 \mathrm{M}$

Perlakuan E : pemberian M-Bio dengan konsentrasi $0,02 \mathrm{M}$
Sebagai bahan baku pembuatan kompos yang digunakan dalam penelitian ini adalah bahan organik berupa sayur-sayuran dari pasar. Sayuran tersebut kemudian dicacah dengan menggunakan golok sampai ukuran yang hampir sama dan disaring dengan menggunakan penyaring.

Aktivator M-Bio dan gula dilarutkan dengan air dengan perbandingan yang sudah ditentukan sebagai perlakuan. M-Bio dan gula yang telah dilarutkan kemudian didiamkan selama \pm 2 jam. Adapun alat yang dibutuhkan adalah sebagai berikut : golok, ember volume 15 liter, terpal ukuran $3 \times 2 \mathrm{~m}$, timbangan bebek, neraca ohaus, gelas ukur, spatula, dan gunting. Sedangkan untuk bahannya antara lain limbah sayuran (kangkung, bayam, wortel, kol, kiciwis, toge), larutan M-Bio, gula pasir, akuades, dedak, dan lakban kertas.

a. Pelaksanaan Penelitian

Sebelum melaksana-kan pengamatan serta per-hitungan kecepatan M-bio, dilaksanakan pembuatan pupuk terlebih dahulu dengan rangkaian kegiatan sebagai berikut:

1) Persiapan bahan pupuk organik limbah sayuran

a) Memotong dan mencacah semua jenis limbah sayuran men-jadi potongan yang lebih kecil

b) Mencampurkan semua sayuran yang sudah dipotong terse-but sampai merata; 
c) Menimbang limbah sayuran yang sudah dicacah tersebut sebanyak 5 sampel masingmasing berat-nya $1 \mathrm{~kg}$, kemudian masing-masing sam-pel dimasukan kedalam ember komposter yang berjumlah 5 buah,

d) Mencampurkan de-dak seberat 250 gr pada masingmasing ember komposter, kemudian mengaduk-nya sampai rata

2) Pembuatan larutan gula dan pengukuran larutan M-Bio

a) Memanaskan aqua-des sebanyak 2 liter sampai suhur 450C

b) Mengukur aquades yang sudah dipanaskan sebelumnya pada gelas ukur dengan ukuran masing-masing, $100 \mathrm{ml}, 200 \mathrm{ml}, 300$ $\mathrm{ml}, 400 \mathrm{ml}$, dan $500 \mathrm{ml}$

c) Melarutkan gula pasir seberat 15 gr pada gelas ukur yang berisi aquades sebanyak $100 \mathrm{ml}, 200 \mathrm{ml}$, $300 \mathrm{ml}, 400 \mathrm{ml}$ dan $500 \mathrm{ml}$

d) Mengukur aktivator M-Bio sebanyak $10 \mathrm{ml}$ sebanyak 5 kali

e) Melarutkan larutan M-Bio sebanyak $10 \mathrm{ml}$ ke masing larutan air gula yang sudah dicampurkan sebe-lumnya

f) Mendinginkan aqua-des, MBio dan air gula selama 2 jam

3) Pencampuran bahan pu-puk organik limbah sayuran, larutan gula dan larutan M-Bio a) Mencampurkan ba-han pupuk organik limbah sayuran dan dedak yang sudah dicampurkan sebelumnya, dengan menambahkan masing-masing pada ember komposter dengan larutan air gula yang ditambahkan larutan M-Bio sebanyak:

(1) Ember kompos-ter I sebanyak $100 \mathrm{ml}$ larutan air gula dan 10 ml M-Bio (0,1 M)

(2) Ember kompos-ter II sebanyak $200 \mathrm{ml}$ air gula dan $10 \mathrm{ml} \mathrm{M-Bio}$ $(0,05 \mathrm{M})$

(3) Ember kompos-ter III sebanyak $300 \mathrm{ml}$ air gula dan $10 \mathrm{ml} \mathrm{M-Bio}$ $(0,033 \mathrm{M})$

(4) Ember kompos-ter IV sebanyak $400 \mathrm{ml}$ air gula dan $10 \mathrm{ml} \mathrm{M-Bio}$ $(0,025 \mathrm{M})$

(5) Ember kompos-ter V sebanyak $500 \mathrm{ml}$ air gula dan $10 \mathrm{ml} \mathrm{M-Bio}$ $(0,02 \mathrm{M})$

b) Menutup rapat ma-singmasing ember komposter dan mem-berikan label volume tingkat konsentrasi laruta M-Bio pada masingmasing em-ber komposter sesuai dengan volume pencampuran larutan sebelumnya

c) Menempatkan semua ember komposter di-tempat yang 
tidak terkena matahari secara langsung

d) Selanjutnya melaksanakan pengamatan fisik setelah proses fermentasi berlangsung

4) Pengamatan dilakukan setiap hari pada pukul 08.00 mulai hari ke dua sampai hari ke tujuh.

\section{HASIL DAN PEMBAHASAN}

1. Hasil Pengamatan I

\begin{tabular}{ccccc}
\hline Konsentrasi & \multicolumn{4}{c}{ Indikator } \\
\cline { 2 - 2 } $\begin{array}{c}\text { larutan } \\
\text { M-Bio \& } \\
\text { Aquades }\end{array}$ & $\begin{array}{c}\text { Tingkat } \\
\text { kekeringan }\end{array}$ & \multicolumn{3}{c}{ Perubahan Fisik } \\
\cline { 2 - 3 } & Basah kering & Warna & Bau & Mikroorganisme \\
\hline $100 \mathrm{ml}$ & $\checkmark$ & $\begin{array}{c}\text { warna awal } \\
\text { campuran sampah } \\
\text { dengan larutan M- }\end{array}$ & $\begin{array}{c}\text { Bau Khas } \\
\text { Sayuran } \\
\text { bercampur }\end{array}$ & $\begin{array}{c}\text { Tidak Terdapat } \\
\text { Mikroorganisme }\end{array}$ \\
\hline $200 \mathrm{ml}$ & $\checkmark$ & $\begin{array}{c}\text { Bio dan dedak } \\
\text { (hijau Tua) }\end{array}$ & $\begin{array}{c}\text { dengan bau } \\
\text { fermentasi }\end{array}$ \\
\hline $300 \mathrm{ml}$ & $\checkmark$ & $\checkmark$ & &
\end{tabular}

\section{Hasil Pengamatan II}

\begin{tabular}{|c|c|c|c|c|}
\hline \multirow{3}{*}{$\begin{array}{c}\text { Konsentrasi } \\
\text { larutan } \\
\text { M-Bio \& } \\
\text { Aquades }\end{array}$} & \multicolumn{4}{|c|}{ Indikator } \\
\hline & $\begin{array}{c}\text { Tingkat } \\
\text { kekeringan }\end{array}$ & \multicolumn{3}{|c|}{ Perubahan Fisik } \\
\hline & Basah kering & Warna & Bau & Mikroorganisme \\
\hline $100 \mathrm{ml}$ & $\sqrt{ }$ & Coklat muda & Bau fermentasi & \multirow{5}{*}{$\begin{array}{l}\text { Tidak Terdapat } \\
\text { Mikroorganisme }\end{array}$} \\
\hline $200 \mathrm{ml}$ & $\checkmark$ & $\begin{array}{c}\text { Mulai } \\
\text { berubah }\end{array}$ & Bau berkurang & \\
\hline $300 \mathrm{ml}$ & $\checkmark$ & Hijau tua & \multirow{3}{*}{$\begin{array}{l}\text { Bau khas } \\
\text { sayuran }\end{array}$} & \\
\hline $400 \mathrm{ml}$ & $\checkmark$ & Hijau tua & & \\
\hline $500 \mathrm{ml}$ & $\checkmark$ & Hijau tua & & \\
\hline
\end{tabular}

\section{Hasil Pengamatan III}

\begin{tabular}{|c|c|c|c|c|c|}
\hline \multirow{3}{*}{$\begin{array}{c}\text { Konsentrasi } \\
\text { larutan } \\
\text { M-Bio \& } \\
\text { Aquades }\end{array}$} & \multicolumn{5}{|c|}{ Indikator } \\
\hline & \multicolumn{2}{|c|}{$\begin{array}{c}\text { Tingkat } \\
\text { kekeringan }\end{array}$} & \multicolumn{3}{|c|}{ Perubahan Fisik } \\
\hline & Basah & kering & Warna & Bau & Mikroorganisme \\
\hline $100 \mathrm{ml}$ & & $\checkmark$ & Coklat tua & Fermentasi & \multirow{5}{*}{$\begin{array}{l}\text { Tidak terdapat } \\
\text { mikroorganisme }\end{array}$} \\
\hline $200 \mathrm{ml}$ & & $\checkmark$ & Coklat tua & Fermentasi & \\
\hline $300 \mathrm{ml}$ & $\checkmark$ & & $\begin{array}{l}\text { Coklat } \\
\text { muda }\end{array}$ & Bau berkurang & \\
\hline $400 \mathrm{ml}$ & $\checkmark$ & & Hijau tua & \multirow{2}{*}{$\begin{array}{c}\text { Masih terdapat } \\
\text { bau khas sayuran }\end{array}$} & \\
\hline $500 \mathrm{ml}$ & $\checkmark$ & & Hijau tua & & \\
\hline
\end{tabular}


Vol. 02, No. 01, Sep 2017

ISSN 2477 - 5193

4. Hasil Pengamatan IV

\begin{tabular}{cccccc}
\hline $\begin{array}{c}\text { Konsentrasi } \\
\text { larutan M- } \\
\text { Bio \& } \\
\text { Aquades }\end{array}$ & \multicolumn{4}{c}{$\begin{array}{c}\text { Tingkat } \\
\text { kekeringan }\end{array}$} & \multicolumn{4}{c}{ Indikator } \\
\cline { 2 - 6 } $100 \mathrm{ml}$ & Basah & kering & Warna & Bau & Mikroorganisme \\
\hline $200 \mathrm{ml}$ & & $\checkmark$ & $\begin{array}{c}\text { Coklat } \\
\text { Kehitaman }\end{array}$ & Tidak berbau & $\begin{array}{c}\text { Tidak terdapat } \\
\text { mikroorganisme }\end{array}$ \\
\hline $300 \mathrm{ml}$ & & $\checkmark$ & Coklat tua & Tidak berbau & $\begin{array}{c}\text { Tidak terdapat } \\
\text { mikroorganisme }\end{array}$ \\
\hline $400 \mathrm{ml}$ & $\checkmark$ & & Coklat & Bau fermentasi & $\begin{array}{c}\text { Tidak terdapat } \\
\text { mikroorganisme }\end{array}$ \\
\hline $500 \mathrm{ml}$ & $\checkmark$ & & Hijau tua & Berbau busuk & $\begin{array}{c}\text { Terdapat sedikit } \\
\text { Larva belatung }\end{array}$ \\
\hline
\end{tabular}

5. Hasil Pengamatan V

\begin{tabular}{cccccc}
\hline $\begin{array}{c}\text { Konsentrasi } \\
\text { larutan M- } \\
\text { Bio \& } \\
\text { Aquades }\end{array}$ & \multicolumn{3}{c}{$\begin{array}{c}\text { Tingkat } \\
\text { kekeringan }\end{array}$} & \multicolumn{4}{c}{ Indicator } \\
\cline { 2 - 6 } $100 \mathrm{ml}$ & Basah & kering & Warna & Bau & Mikroorganisme \\
\hline $200 \mathrm{ml}$ & & $\checkmark$ & Hitam & Tidak berbau & $\begin{array}{c}\text { Tidak terdapat } \\
\text { mikroorganisme }\end{array}$ \\
\hline $300 \mathrm{ml}$ & $\checkmark$ & Coklat Tua & Tidak berbau & $\begin{array}{c}\text { Tidak Terdapat } \\
\text { Mikroorganisme }\end{array}$ \\
\hline $400 \mathrm{ml}$ & $\checkmark$ & & Coklat & Berbau busuk & $\begin{array}{c}\text { Sedikit terdapat } \\
\text { larva belatung }\end{array}$ \\
\hline $500 \mathrm{ml}$ & $\checkmark$ & & Coklat Muda & Berbau busuk & $\begin{array}{c}\text { Larva belatung } \\
\text { semakin banyak }\end{array}$ \\
\hline
\end{tabular}




\section{Hasil Pengamatan VI}

\begin{tabular}{|c|c|c|c|c|c|}
\hline \multirow{3}{*}{$\begin{array}{c}\text { Konsentrasi } \\
\text { larutan M- } \\
\text { Bio \& } \\
\text { Aquades }\end{array}$} & \multicolumn{5}{|c|}{ Indikator } \\
\hline & \multicolumn{2}{|c|}{$\begin{array}{l}\text { Tingkat } \\
\text { kekeringan }\end{array}$} & \multicolumn{3}{|c|}{ Perubahan Fisik } \\
\hline & Basah & kering & Warna & Bau & Mikroorganisme \\
\hline $100 \mathrm{ml}$ & & $\checkmark$ & $\begin{array}{l}\text { Hitam } \\
\text { (Gelap) }\end{array}$ & Tidak Berbau & $\begin{array}{c}\text { Tidak terdapat } \\
\text { mikroorganisme }\end{array}$ \\
\hline $200 \mathrm{ml}$ & & $\checkmark$ & Hitam & Tidak Berbau & $\begin{array}{c}\text { Tidak Terdapat } \\
\text { Mikroorganisme } \\
\end{array}$ \\
\hline $300 \mathrm{ml}$ & & $\checkmark$ & $\begin{array}{c}\text { Coklat } \\
\text { Tua }\end{array}$ & Fermentasi & $\begin{array}{c}\text { Tidak Terdapat } \\
\text { Mikroorganisme }\end{array}$ \\
\hline $400 \mathrm{ml}$ & & $\checkmark$ & $\begin{array}{c}\text { Coklat } \\
\text { Tua }\end{array}$ & $\begin{array}{l}\text { Berbau } \\
\text { Busuk }\end{array}$ & $\begin{array}{l}\text { Larva Belatung Semakin } \\
\text { bertambah }\end{array}$ \\
\hline $500 \mathrm{ml}$ & $\checkmark$ & & $\begin{array}{l}\text { Coklat } \\
\text { Muda }\end{array}$ & $\begin{array}{l}\text { Berbau } \\
\text { Busuk }\end{array}$ & $\begin{array}{l}\text { Larva belatung sudah } \\
\text { menjadi belatung dengan } \\
\text { jumlah yang banyak }\end{array}$ \\
\hline
\end{tabular}

\section{Pembahasan}

Hasil penelitian menunjukkan bahwa pemberian M-Bio dengan konsentrasi yang berbeda memberikan hasil yang berbeda, hal ini dapat dilihat dari kecepatan proses pembentukkan kompos pada setiap pengamatan. Hal ini disebabkan karena proses fermentasi berbeda pada setiap konsentrasi.

Fungsi dan peranan mikroorganisme yang terdapat dalam M-Bio adalah untuk mendekomposisi bahan organik secara fermentasi yang menguntungkan dan menimbulkan aroma yang harum; melarutkan zatzat anorganik dan zat-zat/senyawa organik, membentuk senyawa anti bakteri, antioksidan, dan beberapa senyawa yang merangsang pertumbuhan tanaman; menekan atau mencegah patogen serta mengurangi atau menghilangkan fermentasi yang merugikan (dekomposisi pembusukan dan menimbulkan bau busuk). Hal seperti tersebut ada yang menyebutnya dengan bioremediasi yaitu pemanfaatan biota, khususnya mikroorganisme (bakteri), guna mendegredasi bahan organik atau anorganik berbahaya yang mencemari suatu sumber daya dengan menggunakannya sebagai substrat.

Berdasarkan hasil penelitian ternyata semakin tinggi konsentrasi M-Bio memberikan pengaruh pengomposan yang semakin cepat, artinya pengomposan terjadi dengan cepat terjadi pada konsentrasi tertinggi yaitu dengan konsentrasi 0,1M M-Bio. Hal ini terjadi karena: 1) Ragi/yeast, menghasilkan berbagai enzim dan hormon sebagai senyawa bioaktif untuk pertumbuhan tanaman; 2) Lactobacillus sp., menghasilkan asam laktat meningkatkan dekomposisi atau pemecahan bahan organik seperti lignin dan selolusa; 3) Selubizing Phosphate bacteriae, melarutkan $\mathrm{P}$ 
yang tidak tersedia dalam tanah menjadi bentuk $\mathrm{P}$ yang tersedia bagi tanaman (fungsi $\mathrm{P}$ bagi tanaman sangat penting); 4) Azospirillum sp., mengikat nitrogen udara $\left(\mathrm{N}_{2}\right)$ dan meningkatkan kualitas lingkungan tanah. Konsentrasi 0,1 $\mathrm{M}$ tersebut merupakan konsentrasi yang optimum, sehingga fungsi dan peranan dari mikroba yang terdapat dalam M-Bio tersebut pas untuk mempercepat terbentuknya kompos dari sampah sayuran pasar tersebut.

Pada konsentrasi yang terendah yaitu $\quad 0,02 \mathrm{M}$ M-Bio tidak menghasilkan kompos yang baik malah berbau busuk yang mengakibatkan adanya belatung yang cukup banyak dan terus bertambah banyak. Hal ini disebabkan karena ketika sampah dicampur pada saat penyiapan bahan, bahan tersebut menjadi sangat basah sehingga mikrooganisme yang terdapat pada M-Bio tersebut tidak bisa berfungsi sebagaimana harusnya.

Proses pengomposan mulai terjadi setelah dua hari dalam hal kekeringan kompos yang terbentuk, perubahan warna, dan perubahan bau. Setelah dua hari tersebut pengaruh M-Bio sebagai aktivator mulai bekerja pada konsentrasi 0,1 M. seiring dengan semakin lamanya proses fermentasi yang terjadi, perubahan demi perubahan juga terjadi pada setiap konsentrasi, seperti ditunjukkan pada pengamatan ketiga, keempat, kelima, dan keenam. Yang menunjukkan bahwa adanya pengaruh konsentrasi M-Bio terhadap kecepatan pengomposan sampah sayur pasar. Proses fermentasi pada kelima konsentrasi ternyata tidak menunjukkan hasil yang positif, pada konsentrasi 0,025 $M$ dan 0,02 M kompos yang dihasilkan sangat tidak baik. Selain bau juga menghasilkan mikroorganisme berupa belatung. Hal ini terjadi karena mikroorganisme yang terkandung dalam M-Bio tidak dapat mencegah terjadinya pembusukan dari sampah sayuran tersebut, sehingga yang terjadi adalah pembusukan yang menyebabkan munculnya mikroorganisme yang tidak diinginkan yaitu larva belatung yang kemudian menjadi belatung.

\section{SIMPULAN}

Berdasarkan hasil penelitian yang sudah dilakukan, diperoleh bahwa konsentrasi yang memberikan pengomposan sampah sayur pasar adalah konsentrasi $0,1 \mathrm{M}$; kompos mulai terbentuk pada hari ke dua dan kompos yang optimal terbentuk pada hari ke tiga, dengan fisik: kering, warna coklat tua, tidak berbau, dan tidak ada belatung.

\section{DAFTAR PUSTAKA}

Anonimous. Sustainable Building Sourcebook. Compost System. Sponsored by: Clean Air Gardening. Com. Sustainable Sources, (tersedia: http://www.Greenbuilder.com/ 
sourcebook

contens.html.

Saturday, June, 9, 2001)

Bahar. Yul H. Teknologi Penanganan dan Pemanfaatan Sampah. Jakarta: PT Waca Utama Pramesti, 1986.

Cointreau, Sandra J. Environmental

Management of Urban Solid Waste in Development: a Project Guide. Washington DC: The World Bank, 1982.

Gumbira, Said E.. Sampah: Masalah Kita Bersama. Jakarta: Medyatama Sarana Perkasa, 1987.

Indriani, Yovita Hety. Membuat Kompos Secara Kilat. Jakarta: Penerbit Swadaya, 2000.

Murbandono L.H. Membuat Kompos. Jakarta: Penebar Swadaya, 2000.

Priadi, Rudi dan Iskandar Makmun. Teknologi Pertanian Akrab Lingkungan M-Bio. Yanqoritha, Nyimas, 2012, Optimasi Aktivator dalam Pembuatan Kompos Organik dari Limbah Kakao, Jurnal "Mektek" Tahun XV NO. 2, Mei 2013.
Tasikmalaya: PT Hayati Lestari Indonesia, 2000.

Ramadhan, Aprian P. dan Munawar Ali, Pengolahan Sampah Plastik Menjadi Minyak Menggunakan Proses Pirolisis, Jurnal Ilmiah Teknik Lingkungan Vol. 4 No. 1, Universitas Pembangunan Nasional "Veteran" Jawa Timur.

Soerjani, Mohamad. Pembangunan dan Lingkungan. Meniti Gagasan dan Pelaksanaan Sustainable Development. Jakarta: Institut Pendidikan dan Pengembangan Lingkungan, 1997.

Solid Waste Management Study Group, "Waste Treatment and Final Disposal, Composting and Separation at Source", Waste and Sustainable Development: a Challenge to Environment Education. Jakarta: BPPT, 1992. 